\title{
Airborne synthetic aperture radar analysis of range- land revegetation of a mixed prairie
}

\author{
A.M. SMITH, D.J. MAJOR, M.J. HILL, W.D. WILLMS, B. BRISCO, C.W. LINDWALL, AND R.J. \\ BROWN
}

\begin{abstract}
The authors are post-doctoral fellow and crop physiologist, Agriculture Canada Research Station, Lethbridge, AB T1J 4BI; forage physiologist, Commonwealth Industrial and Scientific Research Organization, Armidale, New South Wales, Australia, 2350; range ecologist, Agriculture Canada Research Station, Lethbridge, AB T1J 4B1; remote sensing specialist, Intera Kenting, Ottawa, ON KIA OY7; tillage engineer, Agriculture Canada Research Station, Lethbridge, AB TlJ 4Bl; remote sensing specialist, Canada Centre for Remote Sensing, Ottawa, ON KIA OY7.
\end{abstract}

\begin{abstract}
Microwave radar is a potentially useful tool for monitoring the condition of the rangeland. A study was conducted in a mixed prairie community at the Agriculture Canada Research Substation at Onefour, Alberta in 1991 to examine the effects of historical management on synthetic aperture radar (SAR) data obtained from 2 aircraft flights, 24 May 1991 and 1 August 1991. Ground-truthing expeditions were conducted on the same days to obtain estimates of vegetation amounts, species distribution and soil moisture. A former grazing experiment established in 1955 and abandoned 20 years ago enabled comparison of 3 grazing treatments, continuous, rotation and free choice superimposed on native range, crested wheatgrass (Agropyron cristatum (L.) Gaertn.) and Russian wildrye (Elymus junceus Fish.). The ground data and imagery were integrated in a Geographic Resource Analysis Support System (GRASS). Fields that had been cultivated and seeded to Russian wildrye had higher radar backscatter than native range. The radar backscatter from crested wheatgrass fields was similar to native range in May but higher than native range in August. Radar backscatter was positively correlated with number of years since seeding with Russian wildrye. Generally there was little difference in radar backscatter with grazing treatment. Correlation analyses between radar digital number extracted from the ground truth sites and vegetation and soil parameters revealed, depending upon swath mode, significant relationships between radar backscatter and the amount of certain grass species, radar backscatter and canopy moisture, and radar backscatter and soil moisture in May. A significant negative correlation was observed between radar backscatter from the August images, in both swath modes, and percent ground cover. The results of this study indicated a role for SAR imagery in evaluating range characteristics.
\end{abstract}

Key Words: radar backscatter, seeding, Russian wildrye, crested wheatgrass, canopy moisture

The mixed prairie ecoregion of the Northern Great Plains in Canada occupies an area of $24 \mathrm{M} \mathrm{ha}$ (Willms and Jefferson, 1993). Monitoring

\footnotetext{
The authors gratefully acknowledge the technical assistance of Mr. Bruce Beasley, Mr. Bob Gschaid, Mr. Craig Andrews, Mr. Greg Travis and Mr. Mike Strate of the Agriculture Canada Research Station, Mr. Ian Kosokowsky and Mr. Roy Penniket of Terrain Resources, Inc., Lethbridge, AB, who worked so diligently procuring ground-truthing data; Mr. Sylver Smoliak for recalling and recording the history of the substation; Mr. Rod Bennen of Alberta Agriculture and his staff for their administrative assistance; Mr. John Naunheimer of the Canada Centre for Remote Sensing for his assistance with the SAR tapes; Alberta Agriculture Research Institute for funding assistance; and, Mr. Dave Satnik and Dr. Ron Owen, Central Washington University, for assistance with GRASS. This paper is Contribution number $\mathbf{3 8 7 9 2 6 2}$ of the Lethbridge Research Station.

Manuscript accepted 6 Jan. 1994.
}

this vast resource by conventional methods is both time consuming and labour intensive. Remote sensing offers a potentially attractive alternative for assessing rangeland condition and productivity. A good relationship exists between range productivity and LANDSAT MSS visible and infrared (VIR) data (Brown et al., 1983). However, the occurrence of few cloud free days even in semi-arid regions reduces the potential for monitoring rangelands using multi-temporal visible and infrared data. Over Western Canada the chance of obtaining a LANDSAT image with less than $20 \%$ cloud cover is only $29 \%$ (Brown et al., 1984).

The cloud penetrating properties of microwaves permit the use of satellite radar in all weather conditions and enable acquisition of strategic date imagery and multi-temporal data on a reliable basis. These properties together with the greater availability of data from the European Remote Sensing Satellite (ERS-1) and the Japanese Earth Resources Satellite (JERS-1), which were launched recently, and the Canadian Space Agency RADARSAT which is due to be launched in 1995 , has stimulated interest in the use of this technology for agricultural monitoring (Brown et al., 1993). The assessment of synthetic aperture radar data from an agricultural perspective is necessary in the development of methods and techniques which will maximize the extraction of crop and soil information. Airborne synthetic aperture radar, hereafter referred to as airborne radar, provides a tool for increasing our understanding of the potential of satellite radar data for monitoring ground vegetation.

Radar backscatter, the microwave energy reflected back to the radar sensor, is primarily influenced by the dielectric constant and surface roughness of the target. As the dielectric constant of water $(\sim 80)$ is much greater than that of dry vegetation or soil $(\sim 3$ to 5$)$ a small change in moisture content of either vegetation or soil causes a large change in the dielectric properties. The volumetric water content of vegetative canopies (Brakke et al., 1981, Major et al., 1991a) and soils (Dobson and Ulaby, 1986) therefore influences radar backscatter. On the tallgrass prairie in Kansas, Martin et al. (1989) found that C-band (4.75 GHz, $63 \mathrm{~mm}$ wavelength) radar backscatter was influenced by green live vegetation as opposed to senescent vegetation which is consistent with moisture being a driving factor.

Target roughness can also influence radar backscatter. Smooth surfaces scatter little or no radar energy while rough surfaces scatter more. Major et al. (1991b) found that tillage increased soil roughness and radar backscatter; the effects being more evident in $\mathrm{C}$ - than $\mathrm{Ku}$ or L-band. C-band is microwave energy of wavelength 3.8 to $7.5 \mathrm{~cm}$ while the $\mathrm{Ku}$ - and L-band have microwave energies of 1.7 to $2.4 \mathrm{~cm}$ and 15 to $30 \mathrm{~cm}$, respectively. Incidence angles of $5-10^{\circ}$ can minimize the effects of target roughness, however, most radar systems function at incidence angles much greater than these.

This study was conducted to further document the use of C-band 
airborne radar for assessing rangeland condition. C-band was chosen because RADARSAT will carry a C-band $\mathrm{HH}$ polarisation radar. $\mathrm{HH}$ polarisation means the radar signal is transmitted and received in the horizontal plane. Application and analysis of radar data in agriculture is still in a relatively early stage of development and the characteristics of agriculturally relevant factors that determine radar reflectivity remain to be elucidated. Thus, ground data were collected at the same time as the airborne radar data to assist in determination of the vegetation and soil factors or characteristics which influence radar backscatter.

\section{Materials and Methods}

\section{Site Description}

The study was conducted in 1991 at the Agriculture Canada Research Substation at Onefour, Alberta (Lat. $49^{\circ}, 0$ to $11^{\prime} \mathrm{N}$, Long. $110^{\circ}, 20$ to $33^{\prime} \mathrm{W}$, elevation $920 \mathrm{~m}$ ) (Figure 1). The region is mostly flat to gently rolling but, in places, is deeply cut by river valleys that are dry most of the year. Drainage is largely into sloughs, although the local drainage basin is a part of the Milk River system, which flows into the Missouri River in Montana.

The soils of the area are mainly light loams. The profile is associated with the residual rock formations which, in this case, are principally Bearspaw and Belly River shales. Practically all of the area has a solonized profile, with characteristic eroded pits due to the patchy removal of the A or surface horizon. These eroded pits may or may not support vegetation. The exposed $B_{1}$ horizon is usually dark in color and very hard which prevents or limits water penetration into the soil.

The climate of the region is characterized by low precipitation, a high rate of evaporation, great extremes of temperature, frequent high winds, and abundant sunshine. The average total annual precipitation is about $280 \mathrm{~mm}$ and the precipitation to evaporation ratio is about 0.35 (Hubbard and Smoliak, 1953). This is the principal climatic factor limiting plant growth. The average annual snowfall of $85 \mathrm{~cm}$ may appear relatively high, but much of it is not normally available for plant growth because the many warm chinook winds sublimate it before it can enter the soil.

The area is representative of the Stipa-Bouteloua community in the mixed prairie ecosystem described by Coupland (1961). Needle-andthread (Stipa comata Trin. \& Rupr.) and blue grama grass (Bouteloua gracilis (H.B.K.) Lag. ex Steud) are the dominant species. Other important grasses include western wheatgrass (Agropyron smithii Rydb.), Junegrass (Koeleria cristata (L.) Pers.) and Sandberg's bluegrass (Poa sandbergii Vasey). Sedges (Carex stenophylla Wahl and $C$. filifolia Nutt.) are common. Common forbs include pasture sage (Artemisia frigida Willd.), dwarf phlox (Phlox hoodii Richards.), broom weed (Gutierrezia diversifolia sarothrae (Pursh) Britt. \& Rusby), winter fat (Eurotia lanata (Pursh) Moa.), salt sage (Atriplex nuttallii S. Wats.) and hoary sage brush (Artemisia cana Pursh). Cactus (Opuntia polyacantha Haw.) is locally common. Little club moss (Selaginella densa Rybd.) is abundant throughout. The average annual dry matter production of this Stipa-Bouteloua community, over a 50 year period, has been estimated at $388 \mathrm{~kg} / \mathrm{ha}$ (Smoliak, 1968). Since 1928 many of the pastures have been plowed and seeded to crested wheatgrass or Russian wildrye.

\section{Synthetic Aperture Radar Acquisition and Processing}

On 24 May 1991 and 1 August 1991, SAR C-band data were obtained using the Canada Centre for Remote Sensing (CCRS) Convair 580 (Livingstone et al., 1987). The frequency and wavelength of the C-band radar were $5.30 \mathrm{GHz}$ and $5.66 \mathrm{~cm}$, respectively. The radar data were collected in HH polarisation and in both the nadir and narrow swath modes (Table 1) to provide multi-parameter data sets
Table 1. Radar operating geometry for Canada Centre for Remote Sensing C-band airborne synthetic aperture radar.

\begin{tabular}{|c|c|c|c|c|}
\hline Mode & \multicolumn{2}{|c|}{ Resolution $^{1}$} & $\begin{array}{c}\text { Incidence } \\
\text { angle }\end{array}$ & $\begin{array}{l}\text { Swath } \\
\text { width }\end{array}$ \\
\hline & & & $(0)$ & $(\mathbf{k m})$ \\
\hline Nadir & 6 & 6 & $0-74$ & 22 \\
\hline Narrow & 6 & 6 & $45-85$ & 18 \\
\hline
\end{tabular}

${ }_{1}$ Range resolution is in the direction perpendicular to the line of flight and azimuth resolution is in the same direction as the line of flight.

across the station. The major difference between nadir and narrow swath modes is the incidence angle with nadir going from 0 to $74^{\circ}$ and narrow going from 45 to $85^{\circ}$.

Four images were processed, a nadir and a narrow mode image for each of the 2 dates. The synthetic aperture radar data were processed at the Agriculture Canada Research Station using the Landsat Digital Imaging Analysis System (LDIAS). A 5 x 5 median filter which reduces speckle but preserves image integrity (Hutton and Brown, 1989) was performed on each image prior to importing them into the Geographical Resources Analysis Support System (GRASS). Each image was registered separately to the map indicating roads and fences illustrated in Figure 1. The resolution specified for the GRASS raster map containing the image was maintained at $6 \mathrm{~m}$.

The image data were not calibrated for each date so the absolute digital number and tones of the imagery cannot be compared. Calibration allows one to compare digital numbers between 2 dates or

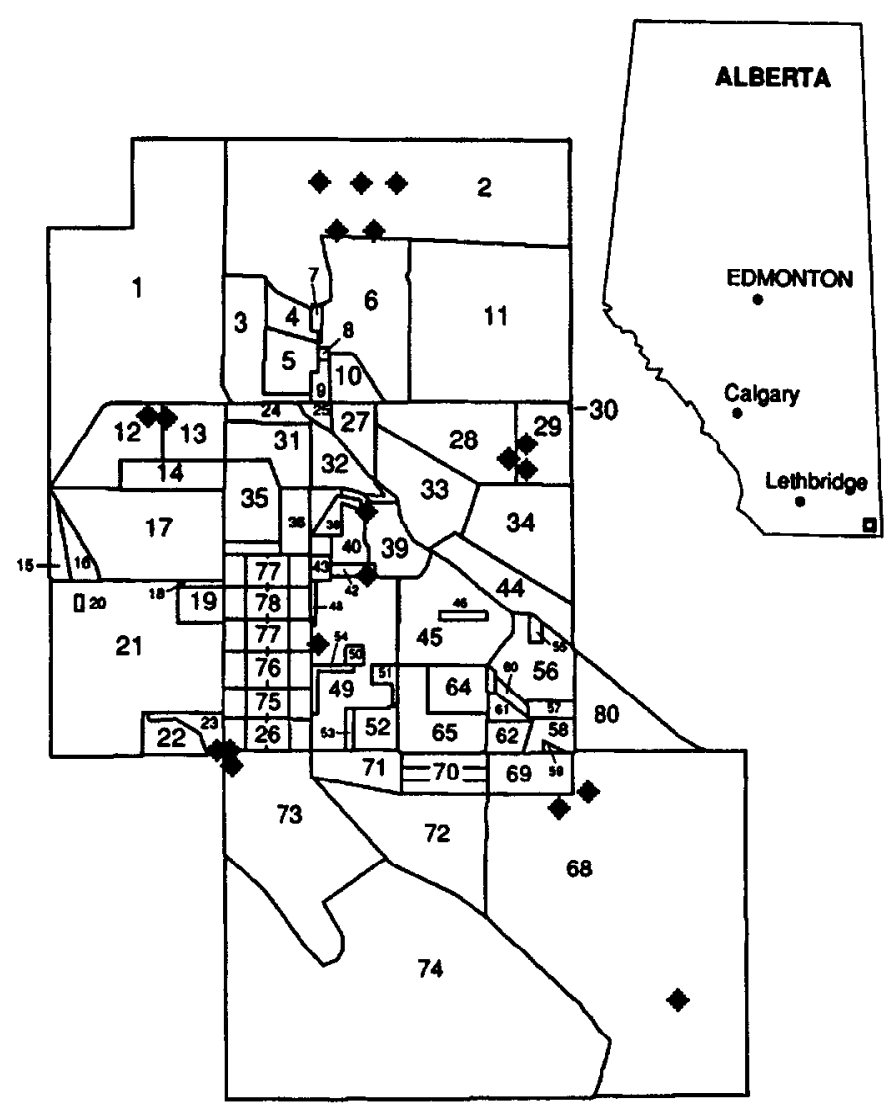

Fig. 1. Map of the Agriculture Canada Substation at Onefour, AB indicating field boundaries and numbers which correspond to Table 1 and sample sites. 
sensors (relative calibration) or to relate digital number to a physical parameter of absolute radar backscatter. Calibration of airborne radar, a difficult and time-consuming problem, is described by Freeman (1992). Relative comparisons among selected targets are, however, valid. The data in this study were analyzed in 3 different components to determine the effects of seeding, the effects of plant community and the effects of soil and vegetation characteristics.

\section{Effects of seeding}

The mean digital number was extracted for each of 49 fields from

Table 2. Listing of fields used for radar backscatter analysis showing seeded grass, year of seeding and area.

\begin{tabular}{|c|c|c|c|c|c|c|c|}
\hline \multirow[b]{3}{*}{ Field } & \multirow[b]{3}{*}{ Vegetation } & \multirow[b]{3}{*}{ Year } & \multirow[b]{3}{*}{ Size } & \multicolumn{4}{|c|}{ Date } \\
\hline & & & & \multicolumn{2}{|c|}{ May } & \multicolumn{2}{|c|}{ August } \\
\hline & & & & Nadir & Narrow & Nadir & Narrow \\
\hline & & & (ha) & $\cdots$ & $-\mathrm{D}$ & c---- & - \\
\hline $8^{\prime}$ & Headquarters & & 5.1 & 73.3 & 98.7 & 60.7 & 113.5 \\
\hline $70^{\prime}$ & Grazing experiment & & 121.0 & 82.2 & 100.8 & 83.3 & 102.4 \\
\hline 13 & Native range & & 119.6 & 71.8 & 96.7 & 73.1 & 83.9 \\
\hline 24 & Native range & & 52.9 & 76.3 & 100.0 & 78.5 & 98.3 \\
\hline 28 & Native range & & 288.8 & 68.1 & 93.9 & 84.0 & 98.6 \\
\hline 31 & Native range & & 145.2 & 71.5 & 97.3 & 75.7 & 88.3 \\
\hline 34 & Native range & & 306.7 & 65.0 & 93.4 & 80.7 & 94.9 \\
\hline 36 & Native range & & 69.7 & 69.9 & 102.8 & 74.5 & 86.9 \\
\hline 44 & Native range & & 171.7 & 68.2 & 98.5 & 82.8 & 101.3 \\
\hline 56 & Native range & & 169.6 & 70.5 & 92.9 & 75.4 & 93.4 \\
\hline 20 & Crested wheatgrass & 1928 & 3.7 & 55.7 & 79.4 & 62.6 & 72.6 \\
\hline 46 & Crested wheatgrass & 1930 & 13.6 & 86.0 & 124.7 & 90.2 & 118.4 \\
\hline 55 & Crested wheatgrass & 1932 & 10.9 & 69.4 & 99.6 & 88.6 & 117.3 \\
\hline 53 & Crested wheatgrass & 1937 & 11.5 & 101.5 & 136.1 & 120.5 & 135.8 \\
\hline 47 & Crested wheatgrass & 1938 & 5.2 & 79.2 & 107.9 & 90.2 & 114.4 \\
\hline 48 & Crested wheatgrass & 1938 & 7.6 & 65.0 & 93.3 & 84.6 & 96.3 \\
\hline 38 & Crested wheatgrass & 1940 & 29.6 & 62.7 & 88.0 & 94.9 & 95.8 \\
\hline 66 & Crested wheatgrass & 1948 & 24.7 & 68.3 & 95.4 & 83.8 & 92.9 \\
\hline 50 & Crested wheatgrass & 1950 & 11.3 & 68.9 & 89.7 & 74.7 & 87.4 \\
\hline 51 & Crested wheatgrass & 1950 & 20.0 & 72.6 & 98.0 & 80.6 & 95.0 \\
\hline 52 & Crested wheatgrass & 1950 & 64.8 & 87.3 & 117.9 & 112.2 & 122.8 \\
\hline 54 & Crested wheatgrass & 1950 & 18.1 & 75.0 & 102.6 & 73.9 & 91.8 \\
\hline 25 & Crested wheatgrass & 1961 & 21.1 & 69.2 & 92.8 & 84.9 & 115.8 \\
\hline 63 & Russian wildrye & 1952 & 25.8 & 97.6 & 130.9 & 105.2 & 134.8 \\
\hline 42 & Russian wildrye & 1956 & 19.6 & 82.3 & 108.6 & 109.3 & 119.8 \\
\hline 57 & Russian wildrye & 1959 & 27.1 & 81.3 & 107.5 & 99.7 & 115.4 \\
\hline 60 & Russian wildrye & 1959 & 15.2 & 85.1 & 115.9 & 101.2 & 120.3 \\
\hline 40 & Russian wildrye & 1960 & 55.8 & 70.0 & 93.7 & 98.8 & 106.6 \\
\hline 26 & Russian wildrye & 1960 & 97.7 & 82.2 & 111.1 & 98.2 & 128.0 \\
\hline 9 & Russian wildrye & 1961 & 25.6 & 93.0 & 127.4 & 70.8 & 130.8 \\
\hline 75 & Russian wildrye & 1961 & 92.8 & 73.3 & 100.9 & 87.0 & 110.0 \\
\hline 61 & Russian wildrye & 1962 & 18.0 & 84.0 & 115.4 & 97.0 & 111.9 \\
\hline 76 & Russian wildrye & 1962 & 109.3 & 87.6 & 118.3 & 83.0 & 107.4 \\
\hline 62 & Russian wildrye & 1963 & 34.6 & 89.2 & 121.1 & 101.7 & 123.7 \\
\hline 77 & Russian wildrye & 1963 & 93.2 & 79.8 & 111.9 & 84.7 & 106.9 \\
\hline 18 & Russian wildrye & 1964 & 9.3 & 68.0 & 98.3 & 88.9 & 103.9 \\
\hline 78 & Russian wildrye & 1964 & 101.3 & 73.2 & 105.9 & 85.1 & 100.6 \\
\hline 64 & Russian wildrye & 1965 & 97.4 & 85.9 & 115.3 & 92.3 & 110.8 \\
\hline 79 & Russian wildrye & 1965 & 92.8 & 72.8 & 101.1 & 83.8 & 101.6 \\
\hline 49 & Russian wildrye & 1966 & 385.0 & 78.3 & 107.5 & 85.4 & 104.8 \\
\hline 19 & Russian wildrye & 1967 & 456.6 & 69.1 & 102.0 & 75.3 & 89.6 \\
\hline 15 & Russian wildrye & 1968 & 39.0 & 67.8 & 97.6 & 71.4 & 83.9 \\
\hline 41 & Russian wildrye & 1968 & 41.3 & 74.2 & 111.3 & 96.2 & 112.0 \\
\hline 43 & Russian wildrye & 1968 & 16.9 & 78.2 & 116.8 & 93.7 & 130.6 \\
\hline 35 & Russian wildrye & 1970 & 154.1 & 69.2 & 101.4 & 82.9 & 95.4 \\
\hline 58 & Russian wildrye & 1970 & 51.0 & 85.6 & 115.5 & 104.7 & 119.5 \\
\hline 10 & Russian wildrye & 1971 & 66.4 & 72.9 & 105.3 & 79.4 & 110.4 \\
\hline 12 & Russian wildrye & 1974 & 206.3 & 75.9 & 105.9 & 86.2 & 96.7 \\
\hline 14 & Russian wildrye & 1974 & 105.3 & 75.0 & 108.3 & 85.1 & 95.2 \\
\hline 65 & Russian wildrye & 1974 & 168.2 & 84.2 & 112.6 & 93.4 & 110.9 \\
\hline 29 & Russian wildrye & 1975 & 155.7 & 74.7 & 105.8 & 93.8 & 113.7 \\
\hline
\end{tabular}

Not used in regression analysis. 
Table 3. Radar backscatter intensities for fields containing native range, Russian wildrye and crested wheatgrass from May and August C-band airborne radar images and for 2 modes, nadir and narrow swath.

\begin{tabular}{lrrrrr}
\hline & \multicolumn{3}{c}{ Date } \\
\cline { 2 - 3 } \cline { 5 - 6 } Vegetation & Narrow & Nadir & & Narrow & \multicolumn{2}{c}{ Nugust } \\
\hline & & & Digital number & \\
\cline { 5 - 6 } \cline { 5 - 6 } Native range & 96.9 & 70.1 & & 93.2 & 78.1 \\
Crested wheatgrass & 103.8 & 75.4 & & 107.0 & 89.9 \\
Russian wildrye & 109.7 & 78.8 & & 110.5 & 90.6 \\
\hline
\end{tabular}

each of the 4 images. The airborne radar image did not cover all of fields 1-11, 68 and 71-74 shown in Figure 1 and thus they were excluded from the analysis. The fields were summarised according to species to which they had been seeded or date of seeding and the digital numbers compared with several fields of native range.

\section{Effects of plant community}

Radar digital numbers were extracted for each plot from a study established in 1954 to evaluate 3 methods of grazing on 3 vegetation types, native range, Russian wildrye and crested wheatgrass (Smoliak, 1968). The study had 3 replications for a total of 27 plots. The grazing systems were (i) season-long over a 6 month period, (ii) free choice, in which the animals could choose Russian wildrye, crested wheatgrass or native range, and (iii) rotation, in which the 3 vegetation types were fenced and grazed in rotation. In the rotation, crested wheatgrass was grazed in the spring for about 2 months, native range during the summer for about 1.5 months and Russian wildrye in the fall for 2.5 months. Data were subjected to analyses of variance.

\section{Effect of soil and vegetation characteristics}

Radar digital numbers from each of the 4 images at each of the ground-truth sample sites were extracted. The extracted data were subjected to a series of correlation analyses to determine the influence of vegetation and soil factors on radar backscatter.

\section{Ground Data}

Ground information, including $35 \mathrm{~mm}$ photographs, was collected at each of 19 sites, designated by the solid diamonds in Figure 1, on the same days as the airborne radar flights. The sites, which were approximately $4 \mathrm{ha}$, were selected to represent the range of different soil and vegetation found on the substation.

The percentage vegetation cover represented by 13 principal plant species was estimated. The species were grouped into native grasses (needle-and-thread, western wheatgrass, blue grama, Junegrass, and Sandberg's bluegrass), tame grasses (Russian wildrye and crested wheatgrass), sedges, palatable forbs (winterfat), unpalatable forbs (pasture sage) and other species (cactus, wild rose and wild onion). The value recorded for each species was an estimate of its percent ground cover.

At each site, five $0.25 \mathrm{~m}^{2}$ samples were clipped and sealed in a plastic bag for dry biomass determination. Samples were weighed and oven-dried at $70^{\circ} \mathrm{C}$ to constant weight. Moisture content of the canopy was calculated from the wet and dry weights.

Soil moisture was measured at each site with a Trase (Soil Moisture Equipment Corp., Santa Barbara, CA) time domain reflectometry instrument developed on the principles described by Topp et al. (1980). In this study, 15-cm probes were used.

On 9 March 1992 and 22 June 1992 surface roughness of selected fields was measured using a truck-mounted device consisting of a small pneumatic wheel (11-cm radius) on a $75 \mathrm{~cm}$ arm mounted on a frame. As the truck moved across the site and the wheel moved vertically with the micro-terrain, the displacement was measured by a potentiometer. A linear relationship existed between potentiometer volt-

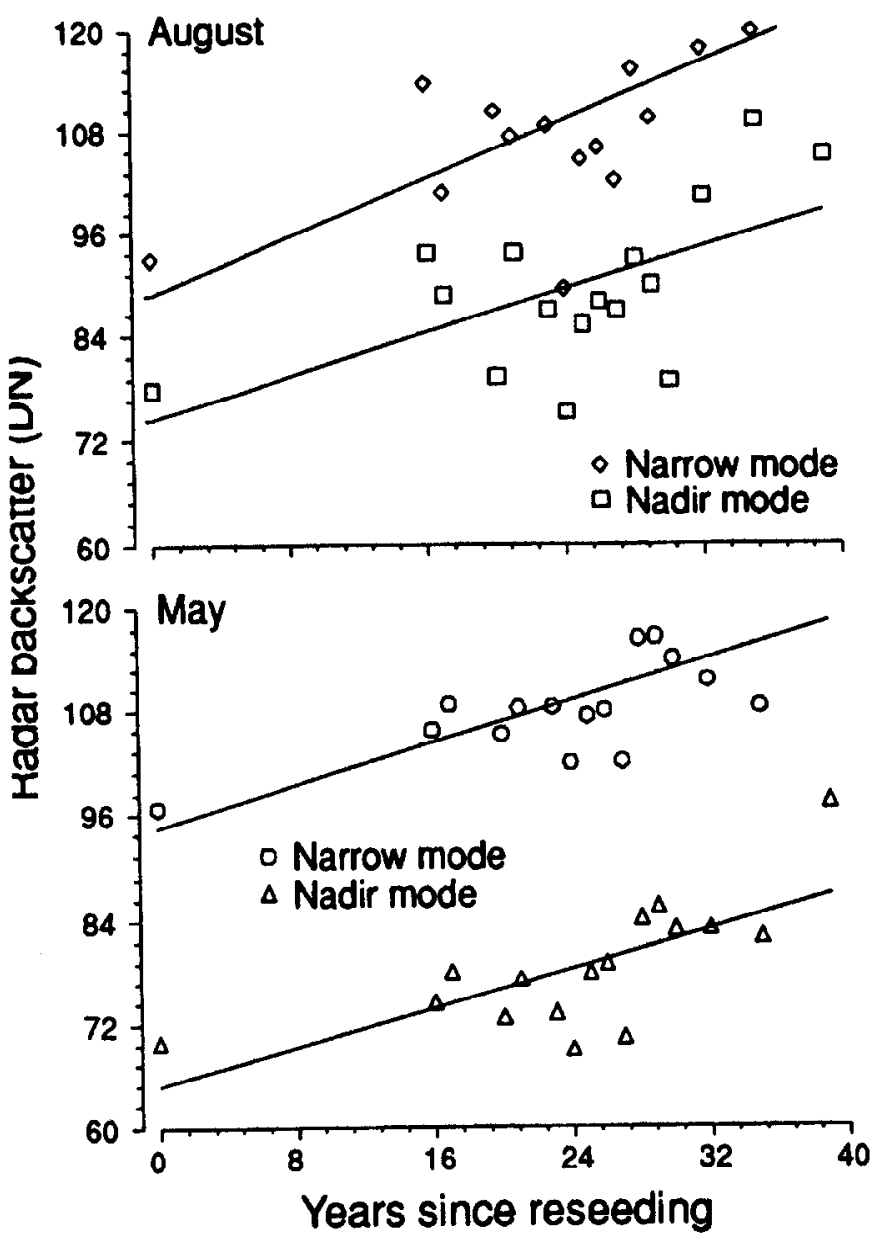

Fig. 2. The relationship between C-band HH radar backscatter and years since seeding to Russian wildrye $\left(D N=94.40+0.61^{*}\right.$ years $r^{2}=0.52$ for May narrow mode, $D N=64.79+57 *$ years $r^{2}=0.49$ for May nadir mode, $D N=88.77+0.85^{*}$ years $r^{2}=0.49$ for August nadir mode, $D N=74.37+$ $0.62^{\star}$ years $r^{2}=0.34$ for August narrow mode).

age and displacement height of the wheel. About 200 measurements were taken and the mean displacement height and the root mean square (rms) height calculated for each site.

\section{Results and Discussion}

In this study we concentrated on vegetation differences of fields and paddocks uniform in elevation and soil. The year and species of seeding, the area and radar digital number are shown in Table 2. On 24 May 1991, average soil moisture content was higher (15\%) than on 1 August (8\%). The first airborne radar flight was scheduled to coincide with maximum live vegetation and the second flight with the cessation of growth. However, 1991 was a wet year and there was still some green vegetation on 1 August. There was considerably more senesced vegetation than in May.

\section{Effects of seeding}

Summarizing radar digital number according to vegetation allowed comparisons of the radar backscatter from a total of 49 fields (Table 2). Russian wildrye had consistently higher digital number than native range (Table 3 ). The digital numbers for crested wheatgrass were intermediate between native range and Russian wildrye in the May images and similar to those for Russian wildrye in the August images.

Thirty-six fields were seeded between 1928 and 1975 and radar backscatter increased with time elapsed since seeding for the 2 SAR 
Table 4. Analysis of variance using radar digital number extracted from a former grazing experiment containing 3 grazing rotations and 3 vegetation types replicated 3 times showing mean squares as well as root mean square errors (r.m.s.e.) and coefficients of variation (c.v. in percent).

\begin{tabular}{lcccccc} 
& & \multicolumn{5}{c}{ Mean Square } \\
\cline { 3 - 4 } \cline { 5 - 6 } Source of & $\begin{array}{c}\text { Degrees of } \\
\text { variation }\end{array}$ & freedom & Nadir & Narrow & Nadir & Narrow \\
\hline Replication & 2 & $85.10^{* *}$ & $129.32^{* *}$ & 9.24 & $289.75^{* *}$ \\
Rotation (R) & 2 & 10.79 & $36.80^{* *}$ & 25.30 & 23.80 \\
Vegetation (V) & 2 & $37.40^{* *}$ & $63.70^{* *}$ & $266.97^{* *}$ & $74.10^{* *}$ \\
R x V & 4 & 2.43 & 3.10 & 4.00 & 12.09 \\
Error & 16 & 3.85 & 5.95 & 10.50 & 19.86 \\
& & & & & \\
c.v. & & 3.27 & 2.44 & 3.83 & 4.33 \\
r.m.s.e. & & 2.88 & 2.44 & 3.24 & 4.46 \\
\hline
\end{tabular}

${ }^{*+} P<0.05$.

dates and modes (Table 2). However, for crested wheatgrass this relationship was not statistically significant $(P>0.05)$. The variability in the digital number of crested wheatgrass with year from seeding may be due, in part, to some fields being located in apparently saline areas and giving a radar backscatter that responded to a modified dielectric constant. The crested wheatgrass field with the highest digital number (53) had a shrub windbreak along the western border of the field which would have contributed to the elevated backscatter. In contrast to crested wheatgrass, at both dates and in both swath modes, a significant positive relationship was found between the radar digital number of Russian wildrye fields and years since seeding (Figure 2). The expectation was that the seeded fields would revert back to native range after a number of years and that the radar backscatter would, therefore, return to values similar to those for native range. Visual observation indicated that native species, such as blue grama, had not recolonized fields except in isolated patches where establishment of seeded species may have failed. However, crested wheatgrass was able to colonize areas between the original rows therefore creating a more uniform microtopography. The differential in radar backscatter observed between crested wheatgrass and native range probably reflects the greater above-ground biomass production by the seeded species.

Preliminary surface roughness measurements revealed a weak positive relationship between radar backscatter and root mean square height. The ground measurements were taken in the year following image acquisition and although it is unlikely that surface roughness changed substantially during this time, further study is required to determine the extent of the seeding-induced erosion phenomenon and whether current revegetation recommendations are appropriate for the mixed prairie.

The steadily increasing radar backscatter with time since seeding suggests that revegetation is not the only factor altering the landscape. Examination of the Russian wildrye fields showed that, over the years, the soil between the rows has eroded leaving the crowns of the plants slightly elevated. In contrast, the surface in native range areas is uniformly smooth, with club moss and other species providing almost complete ground cover. Compared with Russian wildrye, crested wheatgrass fields also appear smoother.

\section{Effect of plant community}

The grazing experiment ended in 1974 and the fences separating plots were removed in 1977 but the experiment and its associated treatments were still apparent in the various airborne radar images, especially in the August nadir mode (Figure 3). The radar digital numbers for each of the 27 plots were extracted and subjected to analyses of variance (ANOVA). The ANOVA results for each of the dates and modes were essentially the same (Table 4). In all 4 ANOVA, digital number significantly differed with vegetation. Radar backscatter from Russian wildrye was higher than that for native range or crested wheatgrass (Table 5). The backscatter for crested wheatgrass was similar to that for native range in the narrow swath but less than and greater than native range in the May and August nadir mode, respectively. Although visually there was an obvious transition from native range to crested wheatgrass, it was not evident in the digital number extracted from all images. In the areas seeded to Russian wildrye, the soil between the rows was badly eroded; consequently these plots have a rougher surface topography and had higher backscatter than those in native range.

Only in the May narrow mode was any difference detected between the 3 rotation treatments. The rms error and the coefficients of variation of the ANOVA were low suggesting good capabilities for discriminating differences.

\section{Effect of soil and vegetation characteristics}

The ground data from each date (Tables 6 and 7) were compared to the radar digital number extracted from the corresponding radar image in the narrow and nadir swath modes. With respect to the May data, radar digital number from the narrow swath mode image was positively related to the moisture content of the plant canopy $(r=0.612)$. The observation that radar backscatter increased with increasing water content of the canopy is consistent with the findings of Brakke et al. (1981) and Major et al. (1991a). In the nadir swath mode, radar digital number was positively and significantly related to gravimetric soil moisture $(r=0.767)$. The influence of soil moisture on radar backscatter has been reported previously (Brisco et al., 1991). In both modes greater correlations would probably have existed between a combination of volumetric soil and canopy moisture and radar digital number (Major et al., 1993), but in the absence of height data canopy moisture could only be calculated on a per area basis.

In the May narrow swath mode, radar digital number increased as the percentage of needle-and-thread and blue grama increased ( $r=$ 0.63 and $r=-0.64$, respectively). Thus, backscatter decreased with an increase in the dominant native species which is consistent with the lower backscatter for the native range discussed previously. Conversely, as Sandberg's bluegrass, forbs and shrubs increased so did radar digital number in the May narrow swath mode $(r=0.66,0.78$ and 0.56 , respectively). In the nadir mode only the amount of western wheatgrass present influenced radar digital number $(r=0.66)$. Analysis of the data for August showed that as ground cover decreased radar digital number increased ( $r=-0.56$ and -0.52 respectively for the narrow and nadir modes). No significant relationship was found between soil moisture and radar backscatter in August.

In summary, the ground data indicated that in May, but not August, radar backscatter in the narrow mode was related to plant characteris-

Table 5. Radar digital numbers from 4 images combining May and August dates and narrow swath and nadir modes, for a grazing experiment utilizing 3 grazing systems and 3 vegetation types at Onefour $\mathbf{A B}$.

\begin{tabular}{lccc}
\hline $\begin{array}{l}\text { Vegetation } \\
\text { Date/Mode }\end{array}$ & $\begin{array}{c}\text { Native } \\
\text { range }\end{array}$ & $\begin{array}{c}\text { Crested } \\
\text { wheatgrass }\end{array}$ & $\begin{array}{c}\text { Russian } \\
\text { wildrye }\end{array}$ \\
\hline May & Digital number & $82.8 \mathrm{a}$ \\
$\quad$ Nadir & $82.4 \mathrm{a}$ & $79.0 \mathrm{~b}$ & $102.8 \mathrm{a}$ \\
Narrow & $99.3 \mathrm{~b}$ & $97.5 \mathrm{~b}$ & \\
& & & $90.3 \mathrm{a}$ \\
August & & $83.3 \mathrm{~b}$ & $106.1 \mathrm{a}$ \\
$\quad$ Nadir & $79.6 \mathrm{c}$ & $101.7 \mathrm{~b}$ & \\
Narrow & $100.7 \mathrm{~b}$ & &
\end{tabular}


Table 6. Vegetation composition of major species (\%), biomass and moisture, soil moisture and ground cover at the 19 ground sites on 24 May 1991.

\begin{tabular}{|c|c|c|c|c|c|c|c|c|c|c|c|c|c|c|}
\hline Site & Field & $\begin{array}{c}\text { Plant } \\
\text { dry weight }\end{array}$ & $\begin{array}{c}\text { Plant } \\
\text { moisture }\end{array}$ & $\begin{array}{c}\text { Soil } \\
\text { moisture }\end{array}$ & NT & WG & BG & JG & SB & SD & PS & RW & $\mathrm{CW}$ & $\begin{array}{c}\text { Ground } \\
\text { cover }\end{array}$ \\
\hline & & $\left(\mathrm{g} / \mathrm{m}^{2}\right)$ & $\left(\mathrm{g} / \mathrm{m}^{2}\right)$ & $(\%)$ & $\cdots$ & & & $\% \mathrm{cc}$ & ition & & & - & & $(\%)$ \\
\hline 1 & 13 & 76.56 & 57.92 & 16.00 & 8 & 6 & 2 & 1 & 1 & 13 & 0 & 0 & 90.6 & - \\
\hline 2 & 12 & 82.34 & 92.32 & 12.78 & 1 & 2 & 1 & 1 & 10 & 3 & 19 & 64 & 0 & 62.0 \\
\hline 3 & 2 & 50.56 & 43.92 & . & 56 & 1 & 6 & 2 & 3 & 6 & 3 & 0 & 0 & 71.0 \\
\hline 4 & 2 & 20.00 & 16.88 & . & 23 & 4 & 6 & 5 & 0 & 2 & 2 & 0 & 0 & 56.0 \\
\hline 5 & 2 & 34.26 & 26.80 & . & 20 & 1 & 3 & 6 & 0 & 5 & 4 & 0 & 0 & 49.0 \\
\hline 6 & 2 & 19.19 & 23.04 & 19.82 & 14 & 11 & 8 & 5 & 0 & 3 & 4 & 1 & 0 & 63.0 \\
\hline 7 & 2 & 22.33 & 22.88 & 21.30 & 16 & 13 & 6 & 4 & 0 & 3 & 9 & 0 & 0 & 68.0 \\
\hline 8 & 68 & 102.70 & 90.30 & 28.89 & 0 & 86 & 0 & 0 & 5 & 0 & 0 & 0 & 0 & 50.0 \\
\hline 9 & 68 & 54.84 & 49.76 & 12.44 & 79 & 5 & 2 & 1 & 2 & 0 & 5 & 0 & 0 & 87.0 \\
\hline 10 & 68 & 79.64 & 40.56 & 11.77 & 79 & 1 & 2 & 5 & 0 & 2 & 6 & 0 & 0 & 74.6 \\
\hline 11 & 28 & 47.68 & 41.20 & 15.00 & 59 & 3 & 4 & 3 & 0 & 2 & 3 & 0 & 0 & 65.0 \\
\hline 12 & 29 & 58.16 & 97.12 & 12.00 & 16 & 3 & 1 & 6 & 3 & 3 & 14 & 24 & 0 & 50.0 \\
\hline 13 & 29 & 76.10 & 106.80 & 16.00 & 2 & 53 & 1 & 2 & 0 & 4 & 3 & 18 & 0 & 68.0 \\
\hline 14 & 39 & 93.24 & 105.36 & 15.47 & 0 & 56 & 0 & 0 & 27 & 0 & 0 & 0 & 0 & 57.0 \\
\hline 15 & 42 & 109.96 & 87.92 & 21.28 & 0 & 2 & 0 & 0 & 0 & 0 & 22 & 76 & 0 & 53.0 \\
\hline 16 & 49 & 107.56 & 106.48 & 13.81 & 36 & 3 & 0 & 1 & 0 & 1 & 5 & 41 & 9 & 55.0 \\
\hline 17 & 23 & 63.92 & 56.40 & 10.32 & 22 & 18 & 17 & 2 & 0 & 18 & 3 & 0 & 0 & 87.0 \\
\hline 18 & 26 & 298.36 & 186.72 & - & 4 & 8 & 0 & 6 & 0 & 4 & 9 & 11 & 48 & 83.0 \\
\hline 19 & 73 & 78.84 & 60.00 & 11.46 & 27 & 14 & 15 & 14 & 3 & 13 & 9 & 0 & 0 & 87.0 \\
\hline
\end{tabular}

NT $=$ needle-and-thread, WG $=$ western wheatgrass, $B G=$ blue grama, JG = Junegrass, SB = Sandberg's bluegrass,

$\mathrm{SD}=$ sedges, $\mathrm{PS}=$ pasture sage, $\mathrm{RW}=$ Russian wildrye, $\mathrm{CW}=$ crested wheatgrass .

tics while that in the nadir mode was related to soil characteristics. The date and mode of acquisition therefore influences the type of information acquired on an airborne radar image.

\section{Conclusions}

This study demonstrated that radar backscatter was influenced by rangeland vegetation. Radar was valuable in differentiating vegetation types, the extent of the differentiation being dependent upon the timing of and the mode of data acquisition. Data acquired in May were more readily related to measurable ground features. The information acquired in the narrow mode primarily reflected plant characteristics while that obtained in the nadir mode primarily reflected soil charac-

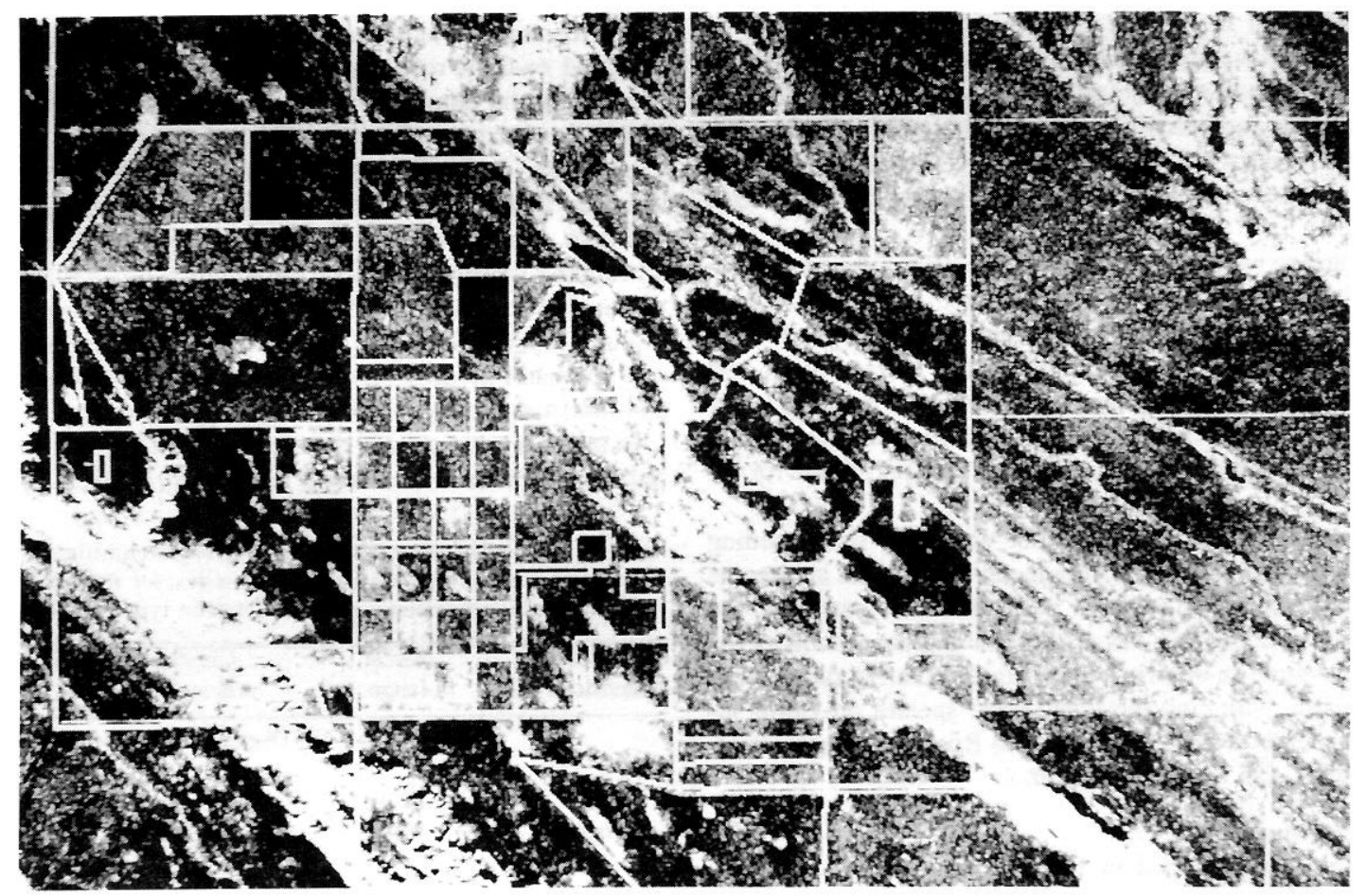

Fig. 3. A C-HH, nadir mode airborne synthetic aperture radar image of the Agriculture Canada Substation at Onefour, AB acquired on 1 Aug. 1991. 
Table 7. Vegetation composition of major species (\%), biomass and moisture, soil moisture and ground cover at the19 ground sites on 1 August 1991.

\begin{tabular}{|c|c|c|c|c|c|c|c|c|c|c|c|c|c|c|}
\hline Site & Field & $\begin{array}{c}\text { Plant } \\
\text { dry weight }\end{array}$ & $\begin{array}{c}\text { Plant } \\
\text { moisture }\end{array}$ & $\begin{array}{c}\text { Soil } \\
\text { moisture }\end{array}$ & NT & WG & BG & JG & SB & SD & PS & RW & $\mathrm{CW}$ & $\begin{array}{l}\text { Ground } \\
\text { cover }\end{array}$ \\
\hline & & $\left(\mathrm{g} / \mathrm{m}^{2}\right)$ & $\left(\mathrm{g} / \mathrm{m}^{2}\right)$ & $(\%)$ & \multicolumn{8}{|c|}{ \% composition } & & $(\%)$ \\
\hline 1 & 13 & 50.44 & 28.84 & 4.62 & 59 & 1 & 3 & 2 & 0 & 2 & 33 & 0 & 0 & 93.0 \\
\hline 2 & 12 & 74.88 & 27.44 & 7.02 & 3 & 3 & 0 & 2 & 0 & 0 & 26 & 57 & 9 & 50.0 \\
\hline 3 & 2 & 141.50 & 68.49 & 9.10 & 36 & 2 & 11 & 13 & 0 & 6 & 25 & 0 & 0 & 25.0 \\
\hline 4 & 2 & 47.58 & 25.93 & 7.50 & 25 & 3 & 21 & 15 & 0 & 5 & 20 & 0 & 0 & 17.0 \\
\hline 5 & 2 & 87.75 & 37.52 & 9.64 & 27 & 13 & 10 & 11 & 0 & 4 & 18 & 0 & 0 & 25.0 \\
\hline 6 & 2 & 58.28 & 46.59 & 10.92 & 36 & 9 & 13 & 12 & 0 & 5 & 25 & 1 & 0 & 5.0 \\
\hline 7 & 2 & 92.74 & 55.09 & 8.00 & 37 & 12 & 10 & 7 & 0 & 4 & 25 & 0 & 0 & 2.0 \\
\hline 8 & 68 & 106.56 & 78.79 & 6.34 & 0 & 85 & 0 & 0 & 4 & 0 & 0 & 0 & 0 & 50.0 \\
\hline 9 & 68 & 57.27 & 26.80 & 6.40 & 62 & 1 & 2 & 4 & 0 & 2 & 15 & 0 & 0 & 90.0 \\
\hline 10 & 68 & 47.40 & 25.39 & 6.04 & 63 & 1 & 5 & 2 & 1 & 1 & 10 & 0 & 0 & 86.0 \\
\hline 11 & 28 & 64.12 & 39.64 & 9.62 & 6 & 11 & 43 & 2 & 0 & 2 & 6 & 0 & 0 & 67.0 \\
\hline 12 & 29 & 80.55 & 40.56 & 7.76 & 18 & 9 & 11 & 1 & 2 & 2 & 7 & 0 & 0 & 44.0 \\
\hline 13 & 29 & 73.41 & 37.62 & 10.08 & 0 & 14 & 1 & 2 & 4 & 5 & 7 & 25 & $\mathbf{0}$ & 46.0 \\
\hline 14 & 39 & 82.68 & 33.80 & . & 23 & 23 & 1 & 0 & 0 & 0 & 40 & 1 & 0 & 51.0 \\
\hline 15 & 42 & 145.12 & 43.35 & 6.98 & 3 & 2 & 1 & 0 & 0 & 0 & 11 & 83 & 0 & 72.0 \\
\hline $\begin{array}{l}16 \\
17\end{array}$ & $\begin{array}{l}49 \\
27\end{array}$ & $\begin{array}{r}87.34 \\
111.54\end{array}$ & $\begin{array}{l}42.65 \\
49.73\end{array}$ & $\begin{array}{r}11.10 \\
5.02\end{array}$ & $\begin{array}{r}0 \\
66\end{array}$ & $\begin{array}{l}0 \\
7\end{array}$ & $\begin{array}{r}0 \\
14\end{array}$ & $\begin{array}{l}0 \\
2\end{array}$ & $\begin{array}{l}0 \\
0\end{array}$ & $\begin{array}{r}0 \\
10\end{array}$ & $\begin{array}{l}1 \\
1\end{array}$ & $\begin{array}{r}88 \\
0\end{array}$ & $\begin{array}{l}9 \\
0\end{array}$ & $\begin{array}{l}35.0 \\
78.0\end{array}$ \\
\hline 18 & 26 & 53.92 & 20.87 & 5.70 & 29 & 5 & 0 & 4 & 0 & 1 & 5 & 0 & 56 & 82.0 \\
\hline 19 & 73 & 150.49 & 59.10 & 4.80 & 40 & 9 & 28 & 0 & 0 & 28 & 1 & 0 & 0 & 74.0 \\
\hline
\end{tabular}

NT $=$ needle-and-thread, WG $=$ western wheatgrass, $B G=$ blue grama, JG = Junegrass, $\mathrm{SB}=$ Sandberg's bluegrass,

$\mathrm{SD}=$ sedges, $\mathrm{PS}=$ pasture sage, $\mathrm{RW}=\mathrm{Russian}$ wildrye, $\mathrm{CW}=$ crested wheatgrass.

teristics. The striking relationship between radar backscatter and the number of years since seeding in the case of Russian wildrye requires further study to determine when and if this pattern reverses. If surface conditions are still changing after more than 60 years, range managers should be aware of this. The detection of year to year differences in range condition are unlikely because changes in range condition occur over a long period.

\section{Literature Cited}

Brakke, T.W., E.T. Kanemasu, J.L. Steiner, F.T. Ulaby, and E. Wilson. 1981. Microwave radar response to canopy moisture, leaf-area index, and dry weight of wheat, com, and sorghum. Remote Sens. Environ. 11:207-220.

Brisco, B., D.J. Major, and R.J. Brown. 1991. Multi-parameter radar backscatter of soil moisture from bare and crop covered fields (preliminary results). Proc. 14th Can. Symp. on Remote Sens., Calgary, AB. 6-10 May 1991, 520-525.

Brown R. J., F.J. Ahern, K.P.B. Thomson, K. Staenz, J. Cihlar, C.M. Pearce, and S.G. Klumph. 1983. Alberta rangeland assessment using remotely sensed data. Canada Centre for Remote Sensing, Res. Rep. 81-1. 128pp.

Brown, R.J., B. Guindon, P.M. Teillet, and D.G. Goodenough. 1984. Crop type determination from multitemporal SAR imagery. Proc. 9th Can. Symp. on Remote Sens., St. Johns, Newfoundland. 14-17 Aug. 1984, 683-688.

Brown, R.J., B. Brisco, R. Leconte, D.J. Major, J.A. Fischer, K.D. Reichert, K.D. Korporal, P.R. Bullock, H. Pokrant, and J. Culley. 1993. Potential applications of Radarsat data to agriculture and hydrology. Can. J. Remote Sens. 19:317-329.

Coupland, R.T. 1961. A reconsideration of grassland classification in the Northern Great Plains of North America. J. Ecol. 49:135-167.

Dobson, M.C. and F.T. Ulaby. 1986. Active microwave soil moisture rescarch. IEEE Trans. Geosci. Remote Sens. 24:23-25.

Freeman, A. 1992. SAR calibration: An overview. IEEE Trans. Geosci. Remote Sens. 30:1107-1121.

Hubbard, W.A., and S. Smoliak. 1953. Effect of contour dykes and furrows on short-grass prairie. J. Range Manage. 6:55-62.

Hutton, C.A., and R.J. Brown. 1989. An evaluation of filter types and sizes. Proc. 6th Symp. L'Association Quebecoise de Teledetection, Sherbrooke, Quebec, 265-278.

Livingstone, C.E., A.L. Gray, R.K. Hawkins, J.G. Halbertsma, R.A. Deane, and R.B. Olsen. 1987. CCRS C-band airbrone radar - system description and test results. Proc 11th Can. Symp. on Remote Sens. Waterloo, ON. 30p.
Major, D.J., B. Brisco, and R.J. Brown. 1991a. Seasonal trajectory of radar backscatter of wheat and canola canopies. Proc. 14th Can. Symp. on Remote Sens., Calgary, AB. 6-10 May 1991, 448-451.

Major, D.J., F.J. Larney, B. Brisco, C.W. Lindwall and R.J. Brown. $1991 b$. Tillage effects on radar backscatter on the semi-arid great plains of north America. Int. Geosci. Remote Sens. Symp. Vol 4:2265-2268.

Major, D.J., A.M. Smith, M.J. Hill, W.D. Willms, B. Brisco and R.J. Brown. 1991. Radar backscatter and visible infrared reflectance from shortgrass prairie. Can. J. Remote Sens. 20:71-77.

Martin, R.D., G. Asrar, and E.T. Kanemasu. 1989. C-band scatterometer measurements of a tallgrass prairie. Rem. Sens. Environ. 29:281-292.

Smoliak, S. 1968. Grazing studies on native range, crested wheatgrass and Russian wildrye pastures. J. Range Manage. 21:47-50.

Topp, G.C., J.L. Davis, and A.P. Annan. 1980. Electromagnetic determination of soil water content: measurements in coaxial transmission lines. Water Res. 16:574-582.

Willms, W.D., and P.G. Jefferson. 1993. Production characteristics of mixed prairie: constraints and potential. Can. J. Animal Sci. 73:765-778. 